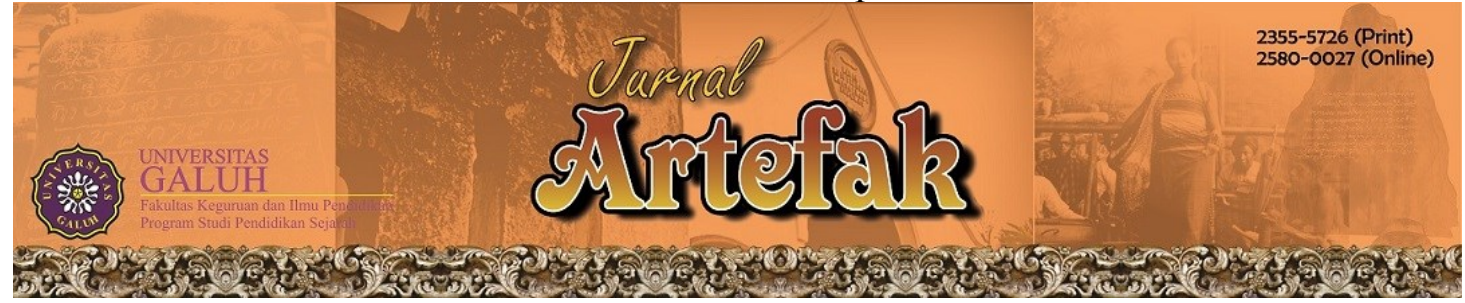

https://jurnal.unigal.ac.id/index.php/artefak

\title{
REVITALISASI EPISTEMOLOGIS PENDIDIKAN KEWARGANEGARAAN: UPAYA MEMINIMALISIR BENCANA SOSIAL
}

\author{
Bali Widodo ${ }^{1}$, Egi Nurholis ${ }^{2}$ \\ ${ }^{1}$ Institut Teknologi Nasional Bandung, Indonesia \\ ${ }^{2}$ Universitas Galuh, Indonesia \\ Jl. PH.H. Mustofa No.23, Neglasari, Kec. Cibeunying Kaler, Kota Bandung, Jawa Barat 40124 \\ Jl. R.E. Martadinata No.150, Mekarjaya, Baregbeg, Kabupaten Ciamis \\ E-mail:baliw@itenas.ac.id, eginurholis@gmail.com \\ Sejarah Artikel: Diterima 19-8-2019, Disetujui 30-8-2019, Dipublikasikan 7-9-2019
}

\begin{abstract}
Abstrak
Tujuan tulisan ini untuk mengetahui bagaimana peranan Pendidikan Kewarganegaraan dalam meminimalisir terjadinya bencana sosial. Dalam perjalanan panjang sejarah bangsa Indonesia, diuraikan secara jelas bahwa negara Indonesia dibangun atas adanya perbedaan suku bangsa, budaya, adat istiadat dan agama. Keberagaman ini rentan untuk terjadinya bencana sosial. Ketegangan sosial dan konflik horisontal serta teror masih acapkali terjadi. Pendidikan Kewarganegaraan sebagai pendidikan nilai dan karakter Pancasila menyiapkan generasi muda menjadi warga negara Pancasilais yang cinta tanah air, mempunyai sikap untuk membela negara dan siap berkorban demi keutuhan bangsa dan negara. Metode penelitian yang digunakan adalah jenis penelitian kualitatif yang bersifat deskriptif terhadap realitas yang ada dengan tujuan untuk mendapatkan kebenaran ilmiah yang alamiah dengan melakukan penafsiran terhadap fenomena sosial dalam bentuk studi literatur. Dari hasil kajian literatur didapat bahwa revitalisasi epistemologis Pendidikan Kewarganegaraan dapat menguatkan karakter bangsa untuk meminimalisir terjadinya bencana sosial.
\end{abstract}

Kata Kunci: Revitalisasi, Epistemologi Pendidikan Kewarganegaraan, Minimalisir Bencana Sosial

\begin{abstract}
This paper is intended to find out how is the role of Civic Education in minimizing the social disasters. In the history of Indonesia's struggle, it is clearly explained that the state of Indonesia is built on the differences in ethnicity, culture, customs and religion. This diversity is vulnerable to social disasters. Terror, social tensions and horizontal conflicts among groups or communities still occur frequently. Civic Education as character education based on Pancasila values prepares young generation to become Pancasilais citizens who love the motherland, have attitudes to defend the country and are ready to sacrifice for the integrity of the nation and state of Indonesia. The research method used is a type of qualitative research that is descriptive towards the existing reality with the purpose of obtaining natural scientific truths by interpreting social phenomenon in the form of literature review. From the results of the literature study it was found that the epistemological revitalization of Civic Education can strengthen the nation's character in order to minimize the social disasters.
\end{abstract}

Keyword: Revitalization, Epistemological Civic Education, Minimize Social Disasters 


\section{PENDAHULUAN}

Sampai saat ini Indonesia masih rentan terhadap adanya bencana. Bencana yang dimaksud meliputi bencana alam, bencana non-alam dan bencana sosial. Bencana alam merupakan kejadian yang disebabkan oleh alam meliputi antara lain berupa tanah longsor, banjir, gempa bumi, gunung meletus, tsunami, kekeringan, angin topan. Bencana non-alam disebabkan karena gagalnya teknologi, epidemi, dan wabah penyakit. Sedangkan bencana sosial disebabkan karena ulah sebagian manusia yang demi kepentingannya mengakibatkan timbulnya konflik horizontal antara anggota masyarakat maupun aksi teror. Bencana sosial perlu penanganan yang sungguh-sungguh karena dampak dari adanya bencana ini dapat merusak keutuhan bangsa dan negara.

Banyak faktor sebagai pemicu timbulnya bencana sosial ini. Misalnya masalah politik terkait pilpres dan pilkada, masalah ekonomi yang berhubungan dengan pemenuhan kebutuhan dasar manusia, dan tidak bijaksana dalam penggunaan teknologi informasi, juga masalah sentimen kesukuan dan keagamaan. Ada sebagian masyarakat yang kurang memahami tentang sejarah panjang bangsa Indonesia. Tentang perkembangan sejarah bangsa Indonesia dari masa kejayaan nasional, penjajahan Barat dan Jepang, masa kebangkitan nasional hingga Proklamasi Kemerdekaan 17 Agustus 1945. Semua berjuang untuk semua tanpa melihat perbedaan suku, budaya dan agamanya. Wajar apabila negara ini pun seharusnya dimiliki bersama pula, bukan milik suatu kelompok, golongan atau agama tertentu saja. Perbedaan etnis, budaya, dan agama yang tidak disikapi dengan bijaksana inilah yang kemudian menimbulkan potensi konflik. Masyarakat lebih terfokus kepada perbedaan latar belakang seseorang bukan persamaannya sehingga mudah terprovokasi untuk melakukan aksi-aksi kekerasan, seolah-olah lupa sebagai anak bangsa yang dulunya dikenal sebagai bangsa yang memiliki kepentingan yang sama dalam melepaskan diri dari penjajahan.

Pemahaman akan sejarah bangsa yang masih kurang inilah yang kemudian dapat memicu adanya konflik atau bencana sosial. Sebagai contoh, memang melekatkan agama sebagai pemicu adanya kekerasan sangat tidak mudah mengingat agama itu sendiri mengajarkan tentang kedamaian dan keselamatan, jauh dari hal-hal yang berbau kekerasan. Wajah sejuk agama tidak mungkin dilekatkan dengan wajah kekerasan. Namun kenyataannya tidak demikian, pemeluk agama menjadikan agama sebagai ideologi hidupnya, dan menjadikan agama ini sebagai faktor pembenar untuk melakukan kekerasan. (Handoko (2006) dalam Muqoyyidin, 2012: 318). Tidak ada yang diuntungkan dengan adanya konflik. Semua dirugikan. Namun demikian, masih banyak oknum anak bangsa yang menggunakan identitas agama untuk kepentingan pribadi dan/atau kelompoknya. Agama seringkali dipolitisasi untuk memperoleh kekuasaan. Berbagai aksi kekerasan, radikalisme dan terorisme yang mengatasnamakan agama menandakan mulai lunturnya ideologi Pancasila terutama dalam implementasi dari sila Ketuhanan Yang Maha Esa. Dapatlah dengan demikian dikatakan bahwa saat ini bangsa Indonesia sedang mengalami krisis nilai-nilai akhlak dan moral. Nilai-nilai luhur budaya bangsa yang tercermin dari sila-sila Pancasila telah mengalami penurunan secara kualitas dalam implementasinya. Padahal kerukunan dalam hidup beragama antar umat yang seagama dan antar umat beragama hanya dapat terwujud apabila Pancasila dijadikan sebagai landasan teologisnya (Mukhlis, 2016: 178)

Banyaknya aksi kekerasan sebagai akibat ulah manusia inilah yang disebut Bencana Sosial. Konflik sosial yang berkaitan dengan isu etnis dan agama tertentu yang paling sering muncul. Kebanyakan kasus yang terjadi akibat ulah seseorang atau kelompok tertentu yang intoleransi terhadap perbedaan yang kemudian dibawa kepada kelompoknya yang lebih luas dengan mengatasnamakan ras, suku, budaya dan agama (Lestari, 2015: 34). Keberagaman bangsa Indonesia dari sisi suku bangsanya, budayanya, adat istiadat dan agamanya rentan untuk terjadinya bencana sosial. Sebagai contoh peristiwa kelam yang terjadi di Tolikara dan Aceh Singkil. Aksi kekerasan berupa pembakaran rumah ibadah atau Masjid yang terjadi di Tolikara dan pembakaran gereja di Aceh Singkil menjadi lembaran hitam intoleransi di Indonesia. Konflik horizontal yang terjadi di kedua daerah tersebut jelas bukan konflik antar 
agama melainkan konflik yang bernuansa agama, yang disebabkan karena masalah kepentingan sebagian orang atau kelompok saja. Selain itu, sering terjadi pula aksi tawuran antar kelompok pelajar, antar kelompok mahasiswa, antar kampung, hal ini juga menunjukkan bahwa negara ini sedang mengalami krisis moral. Seharusnya keberagaman suku bangsa, agama dan kepercayaan, budaya, serta adat istiadat dipahami sebagai karya Tuhan yang terindah bagi bangsa Indonesia yang semestinya harus dijaga dan dipelihara agar tetap ada di bumi Indonesia. Perbedaan akan tetap menjadi masalah yang serius bagi bangsa Indonesia jika terus menerus dipermasalahkan.

Menurut Suparlan (2001: 26) ada beberapa permasalahan pokok yang berpotensi terjadi disintegrasi bangsa maupun wilayah Indonesia, yakni:

a. Penekanan seloka Bhinneka Tunggal Ika lebih kepada keberagaman suku bangsa dan kesukubangsaan bukannya pada keberagaman kebudayaan dan adat istiadatnya;

b. Keberagaman suku bangsa dan kesukubangsaan sering di salah gunakan dalam politik untuk kepentingan dan keuntungan oknum;

c. Coraknya masyarakatnya yang tidak demokratis, meskipun diakui sebagai demokratis. Sebagai negara yang menganut demokrasi Pancasila dalam hal pelaksanaannya justru jauh dari nilai-nilai Pancasila itu sendiri.

Dari apa yang disampaikan di atas dapat dijelaskan bahwa seloka Bhinneka Tunggal Ika lebih membahas tentang orang-orangnya bukan hasil budaya dari orang-orangnya tersebut. Sehingga ketika ada kepentingan salah satu pihak yang dilanggar akan mudah tersinggung dan tersulut api amarah yang berujung kepada aksi kekerasan. Indonesia sebagai negara demokrasi pada kenyataannya belum sepenuhnya nilai-nilai kerakyatan atau demokrasi dilaksanakan dengan baik.

Bencana sosial berupa berbagai aksi anarkhis, premanisme dan brutalisme yang terjadi di negara Indonesia jelas merupakan penyimpangan dari perilaku dan akhlak yang tidak beradab karena mengarah kepada permusuhan, perpecahan bahkan sampai menghilangkan nyawa seseorang. Untuk mengantisipasi makin merebaknya bencana sosial, maka diperlukan revitalisasi epistemologi Pendidikan Kewarganegaraan. Pendidikan Kewarganegaraan yang merupakan pendidikan nilai dan karakter diharapkan dapat membentuk peserta didik untuk lebih mencintai tanah air dan bangga sebagai bangsa Indonesia yang memiliki keragaman suku, budaya dan agama.

\section{METODE PENELITIAN}

Desain Penelitian menggunakan metode pendekatan kualitatif dengan studi literature, yaitu dengan menelaah jurnal atau artikel sebagai data primer, buku, majalah, dan sumber lainnya yang didapat dari internet. Analisa data menggunakan model yang berasal dari Miles dan Huberman yaitu dengan melakukan reduksi data, display, dan penarikan kesimpulan. Peneliti sebagai "human interest" yang menghayati dan mengamati secara langsung berinquiri untuk menemukan gambaran secara umum terhadap realitas yang ada dengan tujuan untuk mendapatkan kebenaran ilmiah yang alamiah dengan melakukan penafsiran terhadap fenomena sosial (Al Muchtar, 2015: 5)

\section{HASIL PENELITIAN DAN PEMBAHASAN}

Implementasi dari semua nilai-nilai yang terdapat dalam Pancasila telah terdegradasi atau mengalami penurunan secara kualitas pelaksanaannya bahkan masih menghadapi berbagai tantangan seperti adanya kesan bahwa Pancasila hanya sebagai simbol artinya belum dilaksanakan secara baik dalam kehidupan sehari-hari, masuknya pengaruh nilai-nilai budaya luar memberikan dampak terhadap sikap dan perilaku generasi muda Indonesia yang tidak selaras dengan nilai-nilai Pancasila, dan mulai lunturnya nilai-nilai nasionalisme dan patriotisme pada bangsa Indonesia sekarang ini. (Triantoro, dalam Maftuh, 2008: 135). Hal-hal inilah yang berpotensi menimbulkan adanya bencana sosial. Bencana sosial harus segera ditangani dengan serius karena dapat mengancam keutuhan bangsa dan Negara Kesatuan Republik Indonesia bangsa. 
Revitalisasi dapat diartikan sebagai proses untuk membuat sesuatu itu menjadi penting atau berharga kembali. Dalam konteks Pancasila, menjadikan Pancasila menjadi sesuatu yang penting kembali dalam kehidupan bangsa Indonesia. Sedangkan epistemologis dapat diartikan sebagai pengetahuan tentang pengetahuan. Jadi epistemologi merupakan dimensi filsafat yang mempelajari asal mula, sumber, struktur, metode, dan sahihnya pengetahuan (Rachman, 2006: 152). Epistemologis sering juga diartikan teori pengetahuan atau theory of knowledge (Suyahmo, 2014: 191)

Menurut Winataputra (2016: 18) epistemologis pendidikan kewarganegaraan adalah domain pendidikan nilai dan karakter. Jadi revitalisasi epistemologis pendidikan kewarganegaraan adalah proses, cara, perbuatan yang dilakukan agar pendidikan nilai dan karakter lebih mendapat perhatian yang serius dalam proses pembelajaran supaya nilai-nilai luhur bangsa Indonesia yang tercermin dalam Pancasila menjadi sesuatu yang penting dalam kehidupan bermasyarakat dan bernegara. Selanjutnya Winataputra (2016, 22-23) menyatakan pula bahwa secara historisepistemologis, perkembangan Pendidikan Kewarganegaraan (civic/citizenship education) tidak terlepas dari situasi politik atau demokrasi di banyak negara, education, in, and for democracy. Oleh karena itu pendidikan termasuk didalamnya Pendidikan Kewarganegaraan merupakan psikopedagogis, sosio-kultural, dan peningkatan kualitas peradaban kemanusiaan.

Peradaban suatu bangsa sangat ditentukan oleh manusia-manusia pada bangsa itu, artinya maju mundurnya peradaban bangsa berkaitan erat atau berhubungan dengan akhlak/ moral nya, sedangkan baik buruknya moral bangsa ditentukan oleh faktor pendidikan. Melalui pendidikan nilai-nilai luhur ditanamkan dalam diri peserta didik (Aeni, 2018: 3). Pendidikan nilai merupakan sarana yang ampuh dalam menjalankan kehidupan sosial dalam suasana demokratis yang tercermin pada kualitas manusianya (Lickona, (1992) dalam Aeni, 2018: 47)

Nilai atau dalam bahasa Inggrisnya "value" adalah kualitas yang inherent atau yang terdapat di dalam sesuatu dan memberikan manfaat bagi kehidupan manusia, baik lahir dan batin (Kaelan, 2001: 174). Nilai adalah esensi atau kualitas atau sesuatu yang berguna dan berharga bagi manusia dalam kehidupan dengan sesamanya (Thoha, 1996: 61), yang berkaitan dengan hal atau tindakan yang baik. Jadi nilai merupakan sesuatu hal yang penting karena akan dijadikan sebagai pedoman dalam setiap tindakan atau perbuatan seseorang dalam hubungannya dengan sesama. Nilai bersifat abstrak, berkaitan dengan idealisme, dan menuntut pembuktian yang bersifat empirik dalam setiap persoalan yang ada (Isna, 2001: 98)

Pancasila sebagai dasar filsafat dan ideologi bangsa-negara Indonesia secara kenyataannya nilai-nilainya masih belum diimplementasikan dengan sungguh-sungguh, artinya belum terinternalisasikan dalam diri bangsa Indonesia, baik dalam kehidupan bermasyarakat, berbangsa, dan bernegara. Pancasila seolah-olah menjadi sesuatu yang tidak penting lagi sebagai falsafah hidup berbangsa dan bernegara (Maftuh, 2008: 135).

Oleh karena itu penanaman nilai-nilai luhur budaya bangsa yang terdapat dalam Pancasila dalam upaya membangun karakter bangsa melalui Pendidikan Kewarganegaraan senantiasa di kembangkan dalam proses pembelajarannya supaya menjadi warga negara yang ber-Pancasilais sejati. Krisis materi pendidikan nilai-nilai Pancasila yang diberikan dalam Pendidikan Kewarganegaraan harus segera diatasi dengan meyakini dan merevitalisasi Pendidikan Kewarganegaraan sebagai pendidikan pembelajaran yang mengacu pada pembentukan karakter Pancasila. Revitalisasi nilai-nilai Pancasila sebagai epistemologi dari Pendidikan kewarganegaraan sangat diperlukan di tengah makin maraknya aksi kekerasan, radikalisme dan fanatisme kelompok yang berlebihan. Revitalisasi nilainilai Pancasila untuk membangun nasionalisme dan patriotisme yang lebih kuat. (Pebriyenni, 2017: 32)

Melalui pendidikan diharapkan peserta didik memiliki komitmen yang kuat dan konsisten dalam mempertahankan Negara Kesatuan Republik Indonesia sebagai negara kebangsaan modern yang pembentukannya didasarkan semangat kebangsaan dalam membangun masa depan bangsa yang lebih baik meskipun berbeda agama, ras, etnik atau golongannya. Negara Republik Kesatuan Indonesia dibangun dengan semangat 
kebangsaan yang berdasarkan kepada nilainilai Pancasila (Akbal, 2016: 490)

Dalam pasal 37 Undang-Undang Nomor 20 Tahun 2003 tentang Sistem Pendidikan Nasional dinyatakan dengan tegas bahwa "...pendidikan kewarganegaraan dimaksudkan untuk membentuk peserta didik menjadi manusia yang memiliki rasa kebangsaan dan cinta tanah air". Berdasarkan undang-undang tersebut dapat jelaskan bahwa Pendidikan Kewarganegaraan mempunyai tujuan untuk menumbuhkan cara pandang atau wawasan dan kesadaran dalam hidup bermasyarakat, berbangsa dan bernegara, memiliki sikap serta perilaku yang cinta pada tanah air, bela negara, dan rela berkorban demi bangsa dan negara serta bersendikan kebudayaan bangsa.

Dalam pasal 4 Undang-Undang Nomor 12 Tahun 2012 tentang Pendidikan Tinggi dinyatakan bahwa fungsi pendidikan tinggi:

a. Mengembangkan kemampuan dan membentuk watak dan peradaban bangsa yang bermartabat dalam rangka mencerdaskan kehidupan bangsa;

b. Mengembangkan civitas akademika yang inovatif, responsif, kreatif, terampil, berdaya saing, dan kooperatif melalui pelaksanaan Tri Dharma;

c. Mengembangkan ilmu pengetahuan dan teknologi dengan memperhatikan dan menerapkan nilai humaniora.

Selanjutnya dalam pasal 5 tentang tujuan pendidikan tinggi dinyatakan bahwa;

a. Berkembangnya potensi mahasiswa agar menjadi manusia yang beriman dan bertaqwa kepada Tuhan Yang Maha Esa dan berakhlak mulia, sehat, berilmu, cakap, kreatif, mandiri, terampil, kompeten, dan berbudaya untuk kepentingan bangsa;

b. Dihasilkannya lulusan yang menguasai cabang ilmu pengetahuan dan/atau teknologi untuk memenuhi kepentingan nasional dan peningkatan daya saing bangsa.

Dalam undang-undang tersebut dijelaskan pentingnya pengembangan karakter kewarganegaraan (civic disposition) sebagai peradaban bangsa yang cerdas, inovatif, responsif, kreatif, memiliki ketrampilan dan berdaya saing dan memiliki kemampuan dalam bidang ilmu pengetahuan dan teknologi.
Budimansyah (2014: 21) menyatakan karakter adalah sifat pribadi yang relatif stabil yang pembentukannya bisa berasal dari dalam maupun dari luar pribadinya yang kemudian dijadikan landasan penampilan perilaku dalam standar nilai dan norma yang tinggi. Dari pendapat tersebut karakter bersifat relatif, bisa berubah tergantung pada lingkungan seseorang itu berada. Selanjutnya Marzuki, dkk. (2011: 18) mengatakan bahwa:

"Karakter identik dengan akhlak sehingga karakter merupakan nilai-nilai perilaku karakter identik dengan universal yang meliputi seluruh aktivitas manusia, baik dalam rangka berhubungan dengan Tuhannya, dengan dirinya, dengan sesama manusia, maupun dengan lingkungannya, yang terwujud dalam pikiran, sikap, perasaan, perkataan, dan perbuatan berdasarkan norma-norma agama, hukum, tata krama, budaya, dan adat istiadat".

Berdasarkan pendapat tersebut, karakter merupakan nilai-nilai perilaku manusia yang meliputi seluruh aktivitas manusia dalam hubungannya dengan Tuhan dan sesama serta lingkungannya.

Menurut Lickona (2012: 64) karakter memiliki tiga bagian yang saling berhubungan yaitu pengetahuan tentang moral, emosi moral, dan tindakan moral. Jadi karakter yang baik dengan mengetahui hal yang baik, menginginkan sesuatu yang baik, dan melakukan perbuatan yang baik; kebiasaan dalam cara berpikir, kebiasaan dalam hati, dan kebiasaan dalam tindakan.

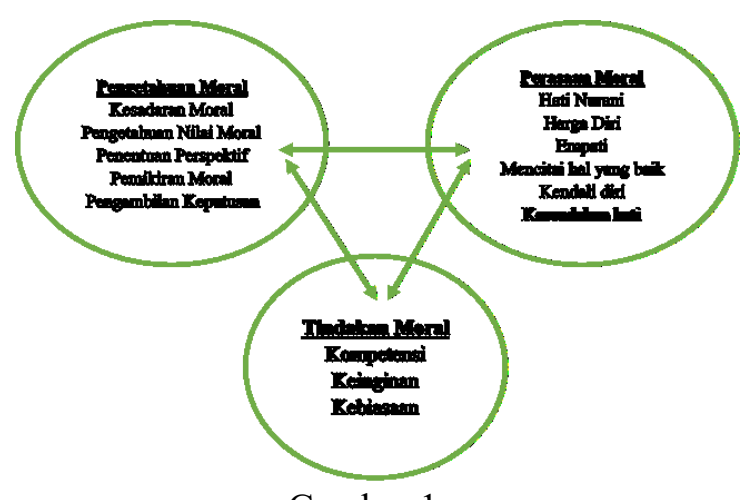

Gambar 1:

Karakter yang berhubungan

Sumber: Buku Educating for Character (Lickona, 1992) 
Karakter bangsa dalam antropologi merupakan tata nilai budaya dan keyakinan dalam kebudayaan suatu masyarakat yang kemudian menjadi ciri khas kepribadian masyarakat tersebut. Dalam konteks bangsa Indonesia untuk memperkuat karakter dengan merevitalisasikan Pancasila dalam semua aspek kehidupan bermasyarakat, berbangsa, dan bernegara (Pebriyenni, 2017: 23)

Dalam pasal 3 Undang-Undang Nomor 20 Tahun 2003 tentang Sistem Pendidikan Nasional dinyatakan:

"Pendidikan nasional berfungsi mengembangkan kemampuan dan membentuk watak serta peradaban bangsa yang bermartabat dalam rangka mencerdaskan kehidupan bangsa, bertujuan untuk berkembangnya potensi peserta didik agar menjadi manusia yang beriman dan bertaqwa kepada Tuhan Yang Maha Esa, berakhlak mulia, sehat, berilmu, cakap, kreatif, mandiri, dan menjadi warga negara yang demokratis serta bertanggung jawab".

Dari pernyataan pasal 3 undang-undang tersebut, karakter kewarganegaraan (civic disposition) yang dimaksud adalah watak kewarganegaraan yang ber-KeTuhananan Yang Maha Esa. Nilai Ketuhanan ini yang harus mendasari dan menjiwai pembentukan watak kewarganegaraan agar menjadi warga negara yang memiliki sikap, perilaku sesuai dengan ajaran agama serta berakhlak mulia (civic virtue).

Dalam nilai Ketuhanan mengajarkan bahwa setiap manusia memiliki harkat dan martabat yang setara atau sejajar di depan Tuhan sehingga harus berlaku adil dan beradab dengan sesamanya. Memperlakukan sesamanya dengan tidak semena-mena. Manusia diciptakan oleh Tuhan untuk saling mengenal, saling mengasihi dan menyayangi, saling tolong menolong.

Dalam Al-Quran (QS. Al-Hujarat: 13) dinyatakan

"wahai manusia! Sungguh, Kami telah menciptakan kamu dari seorang laki-laki dan seorang perempuan, kemudian Kami jadikan kamu berbangsa-bangsa dan bersuku-suku agar kamu saling mengenal. Sungguh, yang mulia di antara kamu di sisi Allah ialah orang yang paling bertaqwa. Sungguh, Allah maha Mengetahui, Maha Teliti”.

Dari QS Al-Hujarat tersebut dapat dikatakan bahwa manusia merupakan makhluk ciptaan Tuhan. Tuhan menciptakan manusia menjadi berbagai bangsa dan suku bangsa dengan berbagai budaya, adat-istiadat, dan agama untuk saling mengenal, saling mengasihi dan saling menyayangi bukan sebaliknya saling bermusuhan.

Sikap saling menghormati dan menghargai antar umat yang seagama dan antar umat beragama harus senantiasa dijaga dan dipelihara untuk mengembangkan etika sosial dalam kehidupan politik-publik sehingga akan memperkuat pembentukan karakter bangsa yang beriman dan berakhlak mulia. Menurut Budimansyah (2010: 46) perilaku bangsa Indonesia yang memiliki nilai Ketuhanan atau ber-Ketuhanan yang Maha Esa adalah sebagai bentuk pengakuan akan eksistensi Tuhan dalam kehidupannya, yang tercermin dalam perilaku iman sebagai pelaku-pelaku firman Tuhan sebagai karakteristik pribadi bangsa Indonesia. Karakter ber-Ketuhanan yang Maha Esa juga tercermin antara lain saling menghargai dan bekerja sama antara pemeluk agama dan penganut kepercayaan; saling menghormati kebebasan menjalankan ibadah sesuai dengan agama dan kepercayaannya itu; tidak memaksakan agama dan kepercayaannya kepada orang lain yang memiliki keyakinan yang berbeda.

Ketuhanan dalam sila pertama Pancasila bukan merujuk pada suatu agama tertentu, tetapi merupakan nilai-nilai moral moral universal dari agama-agama. Pancasila tidak mengarah pada pembentukan negara suatu agama karena akan mematikan pluralitas kebangsaan dan mengesampingkan umat agama yang lain (Latif, 2011: 73). Namun tidak berarti nilai Ketuhanan dipisahkan dari kehidupan negara. Negara tidak memisahkan sama sekali dengan ketuhanan seperti yang dinyatakan secara tegas dalam pasal 29 (1) UUD NRI Tahun 1945 bahwa Negara berdasarkan atas Ketuhanan Yang Maha Esa. Kebebasan dalam berkeyakinan/beragama merupakan hak konstitusional warga negara yang harus dihormati dan dihargai oleh warga negara yang lain. Perbedaan jangan dimaknai sebagai bagian luar kelompoknya atau bahkan 
dianggap sebagai musuh. Perbedaan adalah karunia Tuhan yang senantiasa harus disyukuri karena perbedaan merupakan karya Tuhan yang indah. Pendidikan Kewarganegaraan perlu direvitalisasi sebagai Pendidikan Pancasila yang bertujuan membangun karakter warga negara yang agamis serta berakhlak mulia dalam kehidupan bermasyarakat, berbangsa dalam koridor Negara Kesatuan Republik Indonesia (Al Muchtar, 2019: 180)

Mengupayakan persatuan masyarakat yang plural tentu tidaklah mudah tetapi bukan berarti tidak bisa dilakukan (unity in divesity, diversity ini unity). Hubungan kerjasama, sikap dan perbuatan yang baik yang ditunjuk oleh masing-masing kelompok dalam masyarakat akan mentransformasikan kata kekami-an menjadi ke-kita-an. Kebangsaan Indonesia adalah rasa syukur atas desain sunatullah (hukum Tuhan) yang menciptakan perbedaan atas makhluk ciptaan-Nya dengan menjunjung tinggi kesetaraan (Latif, 2011: 369)

Menurut Maftuh (2008: 136) Revitalisasi epistemologis Pendidikan Kewarganegaraan penting dilakukan agar Pendidikan Kewarganegaraan sarat akan nilai terutama nilai-nilai Pancasila. Berikut ini ada beberapa pemikiran Maftuh (2008: 142) dalam pembelajaran Pendidikan Kewarganegaraan:

a. Pembelajaran PKn hendaknya bermuatan nilai (value-based), sehinga dapat mengembangkan sikap, nilai, moral atau kecerdasan emosional peserta didik;

b. Pembelajaran Pkn harus bermakna (meningful) artinya kemampuan yang dimiliki oleh peserta didik dapat digunakan secara fungsional sepanjang kehidupannya;

c. Pembelajaran PKn berpusat pada keaktifan peserta didik (student centered), misalnya peserta didik diminta untuk memecahkan masalah atau untuk mengambil keputusan;

d. Pembelajaran PKn bersifat komprehensif integral yaitu memadukan antara konsep-konsep keilmuan dengan aspek kognitif, afektif, dan psikomotor;

e. Pembelajaran PKn untuk mengembangkan kemampuan peserta didik dalam cara berpikir kritis, analitis, kreatif, reflektif dan evaluatif;

f. Pembelajaran PKn dilakukan dengan cara demokratis dan dalam suasana yang demokratis, tidak sekedar mengajar apa itu demokrasi;

g. Pembelajaran PKn harus diselenggarakan dalam suasana yang nyaman dan menyenangkan sehingga peserta didik tidak senang karena tidak membosankan. PKn juga diajarkan secara efektif dan efisien, artinya dilakukan secara sederhana, tidak complicated tetapi mampu mencapai target kompetensi atau tujuan yang telah ditetapkan.

h. Pembelajaran PKn hendaknya dikembangkan pula melalui cooperative learning yaitu belajar secara bekerja sama selain untuk meningkat kemampuan akademisnya juga untuk mengembangkan sikapsikap positif seperti menghargai pendapat orang lain, bekerja sama, dan toleransi.

i. Pembelajaran PKn dengan mengajak peserta didik untuk melakukan aktivitas sosial (social action) agar memiliki kepekaan sosial atau kepedulian sosial dan mampu memecahkan masalahmasalah yang ada di masyarakat.

Oleh karena itu, revitalisasi epistemologi Pendidikan Kewarganegaraan dilakukan sebagai upaya penanaman nilainilai Pancasila dengan kata lain sebagai pendidikan watak Pancasila bagi warga negara Indonesia. Menurut Djahiri (2006: 9) Pendidikan Kewarganegaraan adalah wahana titik tolak untuk membangun dan menjaga keberlangsungan nilai-nilai luhur bangsa yang telah berakar pada budaya bangsa Indonesia, yang diharapkan dapat mewujudkan dalam bentuk perilaku kehidupan sehari-hari peserta didik, baik sebagai individu maupun sebagai makhluk ciptaan Tuhan Yang Maha Esa. Dari pernyataan tersebut dapat dijelaskan bahwa Pendidikan Kewarganegaraan bertujuan untuk membentuk warga negara yang memiliki sikap atau perilaku sesuai nilai-nilai luhur dan moral yang telah berurat berakar dalam kehidupan sehari-hari bangsa Indonesia yang kemudian mengkristal dalam bentuk sila-sila yang terdapat dalam Pancasila. 
Dalam pembelajaran Pendidikan Kewarganegaraan peserta didik dikondisikan sebagai pribadi yang kritis, kreatif, dan berperilaku secara cerdas dan baik. Proses pembelajaran dalam bentuk belajar sambil melakukan tindakan (learning by doing), belajar menghadapi dan menyelesaikan masalah sosial (social problem solving learning), belajar melalui pelibatan sosial (socio-participatory learning) untuk penguatan karakter bangsa (Sumardjoko, 2013: 112)

Materi pembelajaran Pendidikan Kewarganegaraan sebagai pendidikan karakter dapat dikembangkan atas wawasan atau cara pandang kesejarahan. Pada saat sidang BPUPKI ketika para pendiri negara memperbincangkan tentang dasar negara bagi Indonesia merdeka terdapat perbedaan pendapat di antara yang hadir. Hal ini memberikan pembelajaran yang amat berharga, betapa perbedaan, pertentangan dan pertukaran pikiran para pendiri negara (founding father) dalam menyiapkan Indonesia merdeka itulah yang sesungguhnya yang mengantarkan kita ke gerbang kemerdekaan. Melalui pertukaran pikiran dari para pendiri negara tampak bahwa perbedaanperbedaan tidak menjadi persoalan. Kenyataan sejarah ini hendaknya dikembangkan sebagai semangat juang untuk bersatu berdasarkan nilai-nilai Pancasila. Kebangsaan Indonesia adalah hasil proses sejarah. Karena itu bagaimana perjuangan bangsa ini dalam membangun negara tidak boleh dilupakan. Menurut Sartono Kartidjo (dalam Amiruddin, 2016) menyatakan bahwa sejarah nasional sebagai tuangan pengalaman kolektif bangsa, merupakan karakteristik bangsa yang bersangkutan. Keberagaman suku bangsa, budaya, adat istiadat, dan agama menunjukkan khasanah budaya bangsa yang harus disyukuri. Kesadaran akan sejarah ini akan menumbuhkan kebanggaan dalam diri setiap warga negara untuk tetap menjaga keutuhan bangsa dan negara. Kemajuan atau kemunduran, eksistensi atau kejatuhan suatu bangsa dan negara tergantung pada generasi penerusnya apakah memiliki kepedulian atau tidak terhadap sejarah dan kebudayaan bangsa yang dimilikinya.

Menurut Amiruddin (2016: 199), kesadaran sejarah dapat dialami oleh seseorang setelah belajar sejarah. Kesadaran akan sejarah dapat menumbuhkan dan membentuk karakter bangsa. Menurut Bryan Garvey dan Mary Krug (dalam Amiruddin, 2016: 199-200) yang disebut belajar sejarah adalah:

a. Memperoleh pengetahuan fakta-fakta sejarah (kognitif);

b. Memperoleh pemahaman atau apresiasi peristiwa-peristiwa atau periodeperiode atau orang-orang masa lalu (afektif);

c. Mendapatkan kemampuan dalam melakukan evaluasi dan memberikan tanggapan terhadap karya-karya sejarah (psikomotorik);

d. Belajar teknik-teknik penelitian sejarah (psikomotorik);

e. Belajar bagaimana menulis sejarah (psikomotorik).

Dapat ditarik simpulan terhadap apa yang disampaikan oleh Bruan Garvey dan Mary Krug bahwa belajar sejarah mempunyai sifat yang komprehensif integral (menyeluruh terpadu) diantara aspek kognitif, afektif, dan psikomotoriknya. Pemahaman pengetahuan sejarah, perilaku orang-orang pada masa sejarah, dan melakukan penelitian terhadap sejarah bangsa akan menumbuhkan dan membentuk karakter bangsa yang tidak pernah melupakan sejarah bangsanya.

\section{KESIMPULAN}

\section{Simpulan}

Beberapa rangkaian peristiwa bencana belakang ini membuktikan Indonesia negara yang rentan terhadap bencana. Tindakan untuk meminimalisir terjadinya bencana terutama bencana sosial perlu mendapatkan perhatian yang serius. Pendidikan Kewarganegaraan sebagai pendidikan nilai dan karakter memiliki peran yang strategis dalam upaya pembinaan mental ideologi, meningkatkan semangat nasionalisme, dan patriotisme para mahasiswa agar menjadi warga negara yang berwatak cinta tanah air, dan memiliki sikap serta perilaku yang mencerminkan nilai-nilai Pancasila. Watak kewarganegaraan yang Pancasilais ini akan menjauhkan mereka dari perilaku anarkhisme, radikalisme dan terorisme sehingga bencana sosial dapat diminimalisir. 


\section{Saran}

Penanganan bencana dilakukan secara simultan yang melibatkan seluruh komponen bangsa, termasuk di dalamnya kalangan civitas akademika. Diharapkan perguruan tinggi untuk memasukkan Mitigasi Bencana dalam kurikulumnya sebagai mata kuliah mandiri atau bisa di insersi pada mata kuliah Pendidikan Kewarganegaraan, Pendidikan Agama atau bisa juga pada Matakuliah Pendidikan Sejarah. Pada prinsipnya peserta didik harus dibekali pengetahuan dasar tentang penanganan bencana terutama bencana sosial.

\section{DAFTAR PUSTAKA}

Aeni, Ani Nur. (2018). Pendidikan Nilai, Moral, Dan Karakter. Bandung: UPI Press.

Akbal, Muhammad. (2016). Pendidikan Kewarganegaraan Dalam Pembangunan Karakter Bangsa. Makassar: Artikel dalam Seminar Nasional "Pendidikan Ilmu-Ilmu Sosial Membentuk Karakter Bangsa Dalam Rangka Daya Saing Global”.

Al Muchtar, Suwarma. (2015). Dasar Penelitian Kualitatif. Bandung: Gelar Pustaka Mandiri.

Al Muchtar, Suwarma. (2019). Pendidikan Kewarganegaraan: Revitalisasi Pengembangan Kurikulum dan Pembelajaran. Bandung: Gelar Pustaka Mandiri.

Amiruddin. (2016). Peran Pendidikan Sejarah Dalam Membangun Karakter Bangsa. Makassar: Seminar Nasional "Pendidikan Ilmu-ilmu Sosial Membentuk Karakter Bangsa Dalam Rangka Daya Saing Global”.

Budimansyah, D. (2010). Penguatan Pendidikan Kewarganegaraan Untuk Membangun Karakter Bangsa. Bandung: Widya Aksara Press.

Djahiri, H.A. Kosasih (2006). Esensi pendidikan Nilai Moral Dan PKN Di Era Globalisasi, Dalam Pendidikan Nilai Moral Dalam Dimensi Pendidikan Kewarganegaraan. Bandung: Laboratorium Pendidikan Kewarganegaraan FPIPS-UPI.

Handoko, Imam P. (2006). Upaya Menjadikan Dunia Lebih Indah. Kompas.
Isna, Mansur. (2001) Diskursus Pendidikan Islam. Yogyakarta: Global Pustaka Utama.

Kaelan. (2001). Pendidikan Pancasila. Yogyakarta: Paradigma

Kartodirdjo, Sartono. (1989). Fungsi Sejarah Dalam Pembangunan Nasional. Dalam HIstorika No. 1 Tahun I. Surakarta: Program Pascasarjana Pendidikan Sejarah Universitas Negeri Jakarta, KPK, Universitas Sebelas Maret Surakarta.

Latif, Yudi. (2011). Negara Paripurna: Historisitas, Rasionalitas, dan Aktualitas Pancasila. Jakarta: Kompas Gramedia.

Lestari, Gina. (2015). Bhinneka Tunggal Ika: Khasanah Multikultural Indonesia Di Tengah Kehidupan SARA. Jurnal Pendidikan Pancasila dan Kewarganegaraan. Nomor 1.

Lickona. (1992). Education for Character, How Our Schools Can Teach Respect and Responsiblity. New York: Bantam Books.

Maftuh, Bunyamin. (2008). Internalisasi Nilai-Nilai Pancasila dan Nasionalisme Melalui Pendidikan Kewarganegaraan. Jurnal EDUCATIONIST, Vol. II, No. 2.

Marzuki, dkk. (2010). Panduan Guru Mata Pelajaran Pendidikan Agama Islam: Pendidikan Karakter terintegrasi dalam Pembelajaran di Sekolah Menengah Pertama. Jakarta: Kemendiknas.

Mukhlis, Febri Hijroh. (2016). Teologi Pancasila: Teologi Kerukunan Umat Beragama. Kudus: Fikrah: Jurnal Ilmu Aqidah dan Studi Keagamaan. Volume 4, Nomor 2. Hal: 171-186 ISSN: 24769649

Muqoyyidin, Andik W. (2012). Potret Konflik Bernuansa Agama Di Indonesia (Signifikansi Model Resolusi Berbasis Teologi Transformatif). Jurnal Analisis, Vol. XII, Nomor 2.

Pebriyenni. (2017). Peran Pendidikan Kewarganegaraan Dalam Memperkuat Karakter Bangsa. Jurnal PPKn \& Hukum, Volume 12, Nomor 2.

Rachman, Maman, dkk. (2006). Filsafat Ilmu. Semarang: UPT-MKU Universitas Negeri Semarang. 
Sumardjoko, Bambang. (2013). Revitalisasi Nilai-Nilai Pancasila Melalui Pembelajaran PKn Berbasis Kearifan Lokal Untuk Penguatan Karakter dan Jati Diri Bangsa. Jurnal Varia Pendidikan, Volume 25, Nomor 2.

Suparlan, Parsudi. (2001). Bhinneka Tunggal Ika: Keanekaragaman Sukubangsa atau Kebudayaan. Yogyakarta: Perhimpunan Indonesia Baru dan Asosiasi Antropolgi Indonesia.

Suyahmo. (2014). Filsafat Pancasila. Yogyakarta: Magnum Pustaka Utama.

Thoha, M. Chabib. (1996). Kapita Selekta Pendidikan Islam. Yogyakarta: Pustaka Pelajar.

Undang-Undang Nomor 20 Tahun 2003 tentang Sistem Pendidikan Nasional

Undang-Undang No. 24 Tahun 2007 tentang Penanggulangan Bencana

Winataputra, U.S. (2016) Posisi Akademik Pendidikan Kewarganegaraan (PKn) Dan Muatan/Mata Pelajaran Pendidikan Pancasila Dan Kewarganegaraan (PPKn) Dalam Konteks Sistem Pendidikan Nasional. 